\title{
OP-ED
}

\section{Is China's Belt and Road Initiative Slowing Down?}

Hong ZHANG ore than seven years since China launched its ambitious Belt and Road Initiative (BRI), a widely held view from the outside is that this endeavour has now slowed down. Such an assessment is typically supported by evidence that China's overseas financing was in decline even before the COVID-19 pandemic. An influential article published in the Financial Times in December 2020 provides a perfect case in point (Kynge and Wheatley 2020). Citing data collected by Boston University showing a sharp drop in the overseas lending of China's two main policy banks in 2019, the article concludes that China is 'pulling back' from the world.

This begs the question of what is the proper measurement of the BRI's progress? Answering this question first requires an accurate conceptualisation of what the initiative is about. Outside China, reports tend to describe the BRI as an infrastructure project and give it a price tag. The same Financial Times article, for instance, refers to the BRI in these terms: 'China has promised to spend about \$1tn on building infrastructure in mainly developing countries around the world-and finance almost all of this through its own financial institutions.' This reflects a common view of the BRI as a centralised deployment of China's financial resources exclusively targeting the infrastructure sector. As such, the BRI's progress is measured by how much funding China can dispatch and how many projects are realised.

How, on the other hand, does the Chinese Government measure the progress of the BRI? A report released in April 2019 by the Office of the Leading Group for Promoting the Belt and Road Initiative (推进“一带一路”建设工作领导小组办公室), the secretariat of the top 
The BRI should instead be seen as an all-out drive to build political, institutional, social, industrial, and financial ties with countries around the world; while infrastructure is the most talked-about element in it, it is not necessarily the most important one. decision-making body for BRI-related issues, provides a template. Progress is reported under the six pillars of the initiative: policy communication, infrastructure connectivity, trade facilitation, financial integration, people-to-people ties, and industrial cooperation (Office of the Leading Group for Promoting the Belt and Road Initiative 2019). They are measured not just by the number of infrastructure projects being implemented, but also by the number of multilateral and bilateral statements endorsing the BRI, initiatives for sectoral cooperation, newly opened logistics channels, trade and taxation agreements, increased flows and new forms of trade, cross-border co-investment funds, lending syndicates, fundraising tools, currency swaps, cultural festivals and tourism events, international scholarships, humanitarian assistance, and overseas industrial parks, among others.

Clearly, not all these activities can be measured in terms of financial value, and relevant outputs of the BRI involve a much wider array of activities than just infrastructure projects. The BRI should instead be seen as an all-out drive to build political, institutional, social, industrial, and financial ties with countries around the world; while infrastructure is the most talked-about element in it, it is not necessarily the most important one. The level of Chinese bank lending is also a poor measurement of the BRI's progress, as these outputs require inputs of not only financial resources, but also diplomatic capital and administrative and technical capacity.

\section{A Pyramid-Shaped System}

With this understanding, we can start to make a more granular analysis of the BRI's content and progress. Here I propose a framework that divides the BRI's activities into four levels in terms of the actors involved, which together can be thought of as constituting a pyramid-shaped system. At the top are the high-level diplomatic engagements leading to the formation of intergovernmental agreements for cooperation. This is also the set of statistics most often used by the Chinese Government when reporting on the progress of the BRI: as of June 2021, 205 documents have been signed with 140 countries and 31 international organisations, the latest being with the Democratic Republic of Congo and Botswana in January 2021 (Xinhua News Agency 2021a, 2021b; yidaiyilu.gov.cn 2021). The majority of these documents are general memoranda of understanding on the 'co-construction of the Belt and Road', which may be no more than a written record of the areas in which both countries have agreed to strengthen cooperation, and which may or may not be followed by concrete action. Only for a small number of countries and organisations-for instance, the African Union, Cambodia, the Czech Republic, Hungary, Kyrgyzstan, Laos, Tajikistan, and Ukraine-has a more concrete 'Cooperation Plan' been 
signed, suggesting a greater specification of objectives and responsibilities. But none of these documents is legally binding and they can be adjusted or reversed, as seen in the recent cancellation of the 'Framework Agreement' between the Victorian State Government in Australia and China's National Reform and Development Commission, as a result of the souring Australia-China relations (State Government of Victoria 2021).

The second level takes into consideration the more technocratic undertakings regarding trade, investment, financial infrastructure, taxation, customs, standards harmonisation, and so on, which involve the relevant central state bureaucracies reaching out to their counterparts in partner countries or proposing new initiatives in international forums with the aim of reshaping the international institutional environment. For example, China's agreements with at least 10 countries on the avoidance of double taxation or tax exemption for certain services have gone into effect since 2016 (State Taxation Administration 2021). Standard harmonisation is another area China is actively pushing, as it recognises the strategic value of increasing the international acceptance of Chinese technical standards. Two three-year action plans have been proposed for the 2015-18 and 2018-20 periods (Xinhua News Agency 2015, 2018), with the goal of completing the standard cooperation mechanisms with all countries along the Belt and Road by 2020 . The plan also includes providing training for foreign governments on Chinese standards through China's foreign aid programs. On top of that, various other central state bureaucracies have issued more than a dozen action plans in the past few years, covering fields including international cooperation in science and technology, energy, agriculture, cultural development, ecological and environmental protection, transport connectivity, language studies, technical standard-setting, and certification and accreditation. There are even plans to promote Chinese traditional medicine and China's animation industry. This layer of activities is largely overlooked in international media reports and thus receives little public attention, but it may be where the most substantive international negotiations are taking place.

The third level is the subnational, where provincial and municipal governments engage in their own economic and cultural diplomacy, depending on their local conditions. For example, Ningxia Hui Autonomous Region, a province in northwestern China with a significant Muslim population and historical ties with the Middle East, has been active in engaging with Arab states. Similarly, the southwestern and southeastern provinces are tapping into their diaspora communities in continental and maritime Southeast Asia to identify new opportunities for engagement. Provincial and municipal governments may also be following in the footsteps of local companies into overseas markets, in their attempt to deepen ties. For example, Jiangsu Province has been actively involved in public 


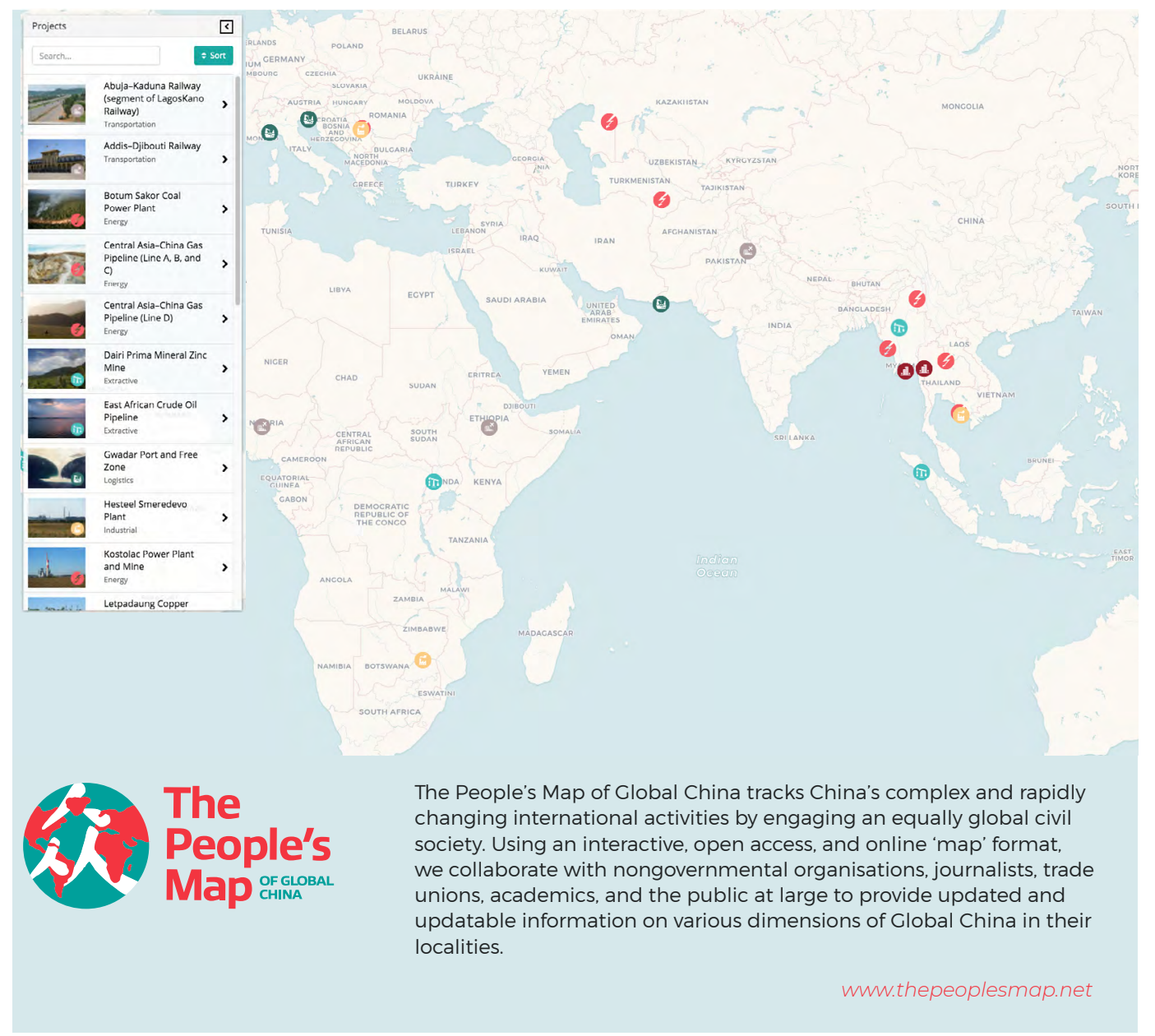

diplomacy and foreign aid programs in Cambodia, because Jiangsu-based manufacturers are very active in that country, including Hongdou Group, a major investor in the Sihanoukville Special Economic Zone.

The fourth level is what most external discussions about the BRI are focusing on: the infrastructure and investment projects carried out by Chinese companies and financial institutions. While the first three levels are largely activities by state actors, this bottom level sees extensive involvement of nonstate market actors as well. These economic activities include not only those with obvious strategic value, such as the construction of key infrastructure projects, but also 'ordinary' commercial activities by both state-owned and private enterprises, such as setting up a garment-making factory. A lot of the state activities in the first three levels are meant to generate and facilitate activities at this fourth level, and the intensified economic 
ties are in turn supposed to tighten social and political relations. Therefore, the BRI cannot be reduced only to the activities at this last level; infrastructure and investment projects must be seen as part of China's comprehensive effort to build international ties.

\section{A Coherent Whole?}

How are the activities at different levels related to each other? Scholars have highlighted the mobilisation of competing domestic interests and the resultant fragmentation in this process (Jones and Zeng 2019; Ye 2019). Indeed, the dialectic relationship between the centralised political authority and local adaptations is perhaps one of the most obscure and least understood aspects of China's governance system: the central political authority sets high-level visions, which are kept purposefully vague and aspirational so they are amenable to local interpretations. Local political leaders-in the bureaucracy, subnational governments, and key state-owned enterprises-are then supposed to interpret these visions and develop localised action plans towards these goals, a process in which their bureaucratic, regional, or corporate interests are taken into consideration to provide proper incentives for further action down the line.

This seeming autonomy in local interpretation is, however, not risk-free. The central political authority still has the ultimate say on whether things are going in the right direction; in the event that certain local attempts go too far or cause disruption, the central political authority can blame local leaders for not doing their jobs well. As the control of personnel is highly centralised in China, this can mean the end of the political career of a local leader. Conversely, if some local attempts prove successful, the local leader may stand a better chance of promotion. In other words, China's governance system is largely result-oriented rather than rules-based, and the system operates with risk-taking at every level of the political hierarchy. As scholars have explained, this system of 'experimentation under hierarchy' emerged during China's economic transition, when the country's leadership had to cope with highly uncertain circumstances (Heilmann 2008). This coping mechanism was activated once again for the BRI as China waded into the unchartered territories of this ambitious new agenda.

Therefore, the various levels of activities are only loosely linked by some vaguely defined notion of the BRI. While the top-level diplomatic activities draw out the broad strategic contours for the BRI, they do not impose strict boundaries or spell out specific instructions for the other layers of activities. It is therefore futile to try to set an exclusionary definition of what a BRI project is: any project can be argued to serve the BRI's tie-building goals if the actors involved can make a plausible case for its potential. Companies have strong incentives to make their projects appear more credible-and many may be actively lobbying for recognition by the Chinese and 
host-country governments-to receive the state's diplomatic and financial support. As many of the BRI target countries are high-risk environments and Chinese companies tend to be inexperienced in these markets, such state support can be critical for their survival in the new ventures.

That of course does not mean that the central political authority endorses every attempt to frame a project as part of the BRI. For example, the Chinese developer of the Shwe Kokko Special Economic Zone in Myanmar presented this project as contributing to the BRI in an attempt to legitimise the highly controversial venture, only for it to be categorically rejected by the Chinese Government after a scandal erupted around activities in the zone (Embassy of the People's Republic of China in the Republic of the Union of Myanmar 2020). However, rather than providing definitional clarity of what is considered a BRI project, the Chinese system is more focused on mobilisation, which is why it has chosen to maintain some 'strategic ambiguity' to activate local incentives to the maximum extent possible.

As the 2019 Office of the Leading Group document cited earlier shows, the BRI produced many outputs. However, while China's mobilisation system may be good at generating quantitative 'outputs', it is not necessarily good at ensuring the achievement of qualitative 'outcomes', especially when the desired outcome is hard to measure. The Chinese political leadership has framed that ideal outcome as 'building a community of a shared future for mankind' (构建人 类命运共同体)-lofty language that does not lend itself to setting tangible milestones. It is not clear how China is examining whether the BRI is approaching this outcome while actors in the system are more geared towards reporting outputs.

Since 2019, after concluding that previous BRI activities had reached a satisfactory level of overall structural coverage, the Chinese political leadership has recalibrated the objective of the BRI to be 'high-quality development' (高质量发展) (Xi 2019). Again, the concept of 'high-quality development' is kept vague except for the statement, inscribed in President Xi Jinping's speech at the Second Belt and Road Forum for International Cooperation, that ' $\mathrm{t}$ ] he BRI must be open, green, and clean, and follow a high-standard, people-centred and sustainable approach'. As in the previous period, various actors in China's bureaucracies, subnational governments, and companies are now competing to interpret the mission statement. As can be expected, actors will likely choose to highlight indicators for which progress is easier to quantify and demonstrate, while qualitative assessment of the complex underlying issues may be sidelined. Meanwhile, external actors are also taking the opportunity to influence the agenda-setting in China. For example, in April 2020, 265 civil society organisations from around the world issued a public statement addressed to the Chinese authorities, which set out 10 principles to ensure that projects are 'high quality', and 
highlighted 60 Chinese-sponsored projects in various sectors that do not meet these criteria (Civil Society Groups 2020). It is not clear how the Chinese Government is responding to such suggestions.

\section{Towards Proper Measurement of the BRI}

Going back to the view about the slowdown of the BRI mentioned at the beginning of this article, it may not be an accurate assessment due to the improper measurement methods adopted. Even if overseas lending has dropped from previous years, we need to see whether trade and investment flows are following the same trend. According to Chinese official statistics, trade in goods with the 64 Asian and European countries in the originally conceived Belt and Road regions increased by 6 per cent and 0.7 per cent in 2019 and 2020, respectively, while China's outward foreign direct investment in these countries dropped by 7.6 per cent in 2019 before bouncing back to a 18.3 per cent growth in 2020 . Notably, the rebound of investment into these countries took place against the backdrop of a dip in China's outward investment globally. But besides these economic activities, the diplomatic activities on the first three levels analysed above have continued to build, the tracking of which requires a more sophisticated BRI 'accounting' system. The more challenging task, however, is to evaluate the quality of these outputs, and that will take some serious collective efforts by researchers around the world. 
This text is taken from Made in China Journal: Volume 6, Issue 1, 2021, edited by Ivan Franceschini and Nicholas Loubere, published 2021 by ANU Press, The Australian National University, Canberra, Australia.

doi.org/10.22459/MIC.06.01.2021.01 